\title{
Pola Asuh Orangtua dalam Mengantisipasi Dampak Penggunaan Gadget di Masa Pandemi Covid-19
}

\author{
Najwa \\ Universitas Islam Negeri (UIN) Sunan Kalijaga Yogyakarta \\ syifahumairah06@gmail.com
}

\begin{abstract}
This study aims to determine how parents' upbringing on children's behavior in playing gadgets during the pandemic. This study uses a qualitative method with a phenomenological approach. From the results of the study, it can be concluded that the parenting style applied to children in playing gadgets generally uses democratic parenting. Parents' parenting behavior in responding to children who play with gadgets tends to use a gentle way, giving understanding to children about the negative effects of playing gadget and giving freedom to children to express themselves but still under strict supervision and control so that children use gadget for things the positive.
\end{abstract}

Keywords: Parenting Style; Impact of Gadgets; Children's Behavior

\begin{abstract}
Abstrak
Penelitian ini bertujuan untuk mengetahui bagaimana pola asuh orang tua terhadap perilaku anak dalam bermain gadget di masa pandemi. Penelitian ini menggunakan metode kualitatif dengan pendekatan fenomenologis. Hasil penelitian, dapat disimpulkan bahwa pola asuh orangtua yang diterapkan terhadap anak dalam bermain gadget secara umum menggunakan pola asuh demokratis. Poa asuh orang tua dalam menyikapi anak yang bermain gadget cenderung menggunakan cara lemah lembut, memberikan pengertian kepada anak tentang dampak negatif dari bermain gadget dan memberikan kebebasan pada anak untuk mengekspresikan dirinya namun tetap pada pengawasan dan kontrol yang ketat agar anak menggunakan gadget untuk hal-hal yang positif.
\end{abstract}

Kata Kunci: Pola asuh; dampak gadget; perilaku anak 


\section{Pendahuluan}

Negara Indonesia saat ini sedang dihadapkan dengan wabah atau virus yang disebut dengan covid-19. Covid-19 tidak hanya di Indonesia, namun seluruh dunia merasakan pandemi ini. Kini pandemi menjadi musibah yang sangat mengglobal. Awalnya virus ini muncul dari Negara Wuhan RRC pada bulan Desember 2019 dan kemudian terus merambat ke seluruh belahan dunia, sekarang dunia harus berperang melawan virus yang hanya bisa dilihat dengan alat miskroskop, virus berukuran kecil ini telah mampu menggencarkan, membuat kecemasan, kekhawatiran dan bahkan mengancam nyawa jutaan manusia. Tidak hanya itu, dampak yang ditimbulkan akibat covid 19 juga banyak dirasakan oleh masyarakat. Terutama dari segi pendidikan, anak-anak yang kini terpaksa harus menggunakan gadget sebagai alternatif untuk sekolah online.

Gadget merupakan suatu alat komunikasi yang memiliki banyak fungsi dan kegunaan. Berbagai macam dapat diperoleh di dalamnya. Gadget sekarang sudah menjadi kebutuhan yang sangat penting bagi kehidupan masyarakat modern, tidak hanya menjadi alat komunikasi tetapi dapat memberikan informasi dan memudahkan orang dalam berkomunikasi. Gadget memiliki pengaruh besar terhadap kehidupan manusia. Seperti halnya gadget memberikan dampak yang begitu besar pada anak-anak di masa pandemi ini. Sehingga penggunaan alat komunikasi semakain meningkat di era pandemi Covid 19.

Pada masa pandemi ini banyak sekali anak-anak yang sudah terbiasa menggunakan atau mengoperasikan gadget sebagai media untuk belajar, akan tetapi gadget juga digunakan untuk bermain game dan membuat anak-anak menjadi kecanduan menggunakan gadget. Banyak yang menganggap bahwa gadget bisa merusak perkembangan ataupun perilaku psikologis anak. Sebenarnya gadget tidak hanya menimbulkan dampak negatif bagi anak tetapi juga memiliki dampak positif. Diantaranya dapat membentuk pola pikir anak dalam mengatur kecepatan, mengolah strategi dalam permainan dan membantu meningkatkan kemampuan otak anak selama dalam pengawan yang baik. Apabila tanpa pengawasan yang terarah dari orangtua perkembangan anak akan mengarah pada sisi yang negatif. Orangtua dituntut lebih kreatif, berwawasan luas dan selalu menggunakan berbagai metode sehingga dapat menunjang kesempatan untuk anak dalam mengembangkan prestasi yang anak miliki, terutama dimasa pandemi ini.1Orang tua secara umum mempunyai peran sebagai pembimbing, pendidik, penjaga, pengembang dan pengawas. 2 Karena

${ }^{1}$ Serli Marlina, "Peningkatan Sikap Sosial Anak Usia Dini Melalui Permainan Puzzle Buah Di Taman Kanak-Kanak Aisyiyah 1 Bukittinggi," Pedagogi: Jurnal Ilmu Pendidikan 14, no. 2 (November 1, 2014): 109-114.

${ }^{2}$ H. Jamaluddin Hos Juhardin, "Dampak Pola Asuh Orang Tua Terhadap Perilaku Anak (Studi di Desa Amberi Kecamatan Lambuya Kabupaten Konawe)," Jurnal Neo Societal 1, no. 0 (July 20, 2016), accessed January 10, 2021, http://ojs.uho.ac.id/index.php/NeoSocietal/article/view/9526. 
peran orangtua sangat penting dalam proses perkembangan psikologi anak. Orangtua harus cermat dalam membimbing anak, mengarahkan anak kepada hal yang baik dalam penggunaan gadget agar hasil yang diperoleh dapat maksimal.

Pandangan psikolgis masa anak-anak adalah masa keemasan di mana anak-anak belajar segala sesuatu yang belum diketahuinya. Jika masa anak-anak sudah terbiasa melakukan hal-hal buruk, maka perkembangan anakpun akan terhambat, karena pengalaman masa kecil mempunyai pengaruh yang kuat terhadap perkembangan berikutnya. Sebenarnya gadget tidak hanya menimbulkan dampak negatif tetapi juga memiliki dampak positif bagi anak.3 Eka Setiawati, dkk, menyarankan bagi orang tua untuk menemani anak-anak mereka dalam menggunakan gadget serta menyediakan batas waktu, memeriksa gadget dan memilih game dan aplikasi tontonan yang dapat mengasah perkembangan anak.4

Berdasarkan hasil penelitian di atas, pada dasarnya perilaku anak tidak sepenuhnya dipengaruhi oleh gadget, akan tetapi dipengaruhi oleh cara atau pola asuh orangtua terhadap anak. Pola asuh yang tidak terarah dengan baik akan berpengaruh pada perilaku anak itu sendiri sehingga memberikan dampak negatif terhadap perkembangannya. Perilaku yang baik berasal dari pola asuh orangtua yang baik.5 Pola asuh orangtua merupakan tata cara mendidik, memelihara dan membimbing keluarga ke arah positif, orang tua harus meletakan dasar-dasar moral, etika baik itu sikap dan perilaku yang baik kepada anak-anaknya sehingga tercipta sesuatu yang bermanfaat bagi diri sendiri, keluarga maupun masyarakat sekitar.6

Penemuan lain juga menegaskan bahwa pola asuh orangtua memiliki dampak yang positif, terlebih pada pola asuh ibu terhadap anak. Karena pada halnya ibu menjadi madrasah utama bagi anak.7 Indian Sunita dan Eva Mayasari juga menegaskan bahwa peran orangtua dalam mendidik anak harus selalu cermat terlebih lagi ketika anak seringkali bermain gadget, peran orangtua sangat diperlukan dalam pengawasan untuk memberikan arahan yang terbaik bagi anak dikarenakan fasilitas yang ada pada gadget tidak hanya memberikan dampak positif, tetapi juga sebaliknya. Oleh sebab itu orangtua harus selalu memperhatikan masa perkembangan yang terjadi pada anak. 8

${ }^{3}$ Nanang Sahriana, "The Importance of the Role of Parent in the Use of the Gadget at Early Childhood”, Journal Smart PAUD, 2019, hlm. 60.

${ }^{4}$ Eka Setiawati, Elih Solihatulmillah, Habib Cahyono," "The Effect of Gadget on Children's Social Capability", Journal of Physics: Conference Series, 2019, hlm. 1

${ }^{5}$ Dewi Fortuna, Solina, Digital Parenting Terbadap Anak Pada Masa Pandemi Covid-19, Universitas Padjadjaran.

${ }^{6}$ Anisah, A. S. (2017). Pola asuh orang tua dan implikasinya terhadap pembentukan karakter anak. Jurnal Pendidikan UNIGA, 5(1), 70-84.

7 Susan, M shaw. Family Leisure and Changing Ideologies of Parenthood, Journal Compilation: Sosiology Compas,2008, hlm. 689.

${ }^{8}$ Indian Sunita \& Eva Mayasari, Pengawasan Orangtua Terhadap Dampak Penggunaan 
Paparan pola asuh orang tua yang telah dibahas di atas, lebih banyak diteliti saat sebelum terjadinya pandemi yang mana lebih menekankan pada pengasuhan, pengawasan dan penjagaan yang baik untuk anak, sementara di masa pandemi ini anak-anak lebih banyak di rumah sehingga semua fasilitas baik itu gadget, televisi lebih banyak digunakan oleh anak. Sementara itu penelitian yang terkait dengan pola asuh orang tua saat terjadi pandemi merupakan penemuan baru di tahun ini dan belum banyak yang melakukan.

Berdasarkan hal tersebut di atas, kajian dalam penelitian ini menjadi sangat penting dilakukan untuk memahami bagaimana sebenarnya pola asuh orang tua dan dampaknya terhadap pengunaan gadget di masa pandemi covid 19.

Penelitian ini menggunakan metode kualitatif dengan pendekatan fenomenologis. Fenomenologis merupakan suatu metode yang bertujuan mendiskripsikan, mengkaji, serta memahami suatu kejadian yang dialami oleh seseorang, berupa perubahan sikap ataupun perubahan perilaku orang yang benar-benar mengalami kejadian tersebut (Jhon W. Creswell, 2019). Subjek dalam penelitian ini berjumlah 5 orang yang berstatus orangtua, baik itu ayah ataupun ibu dengan kesepakatan mencantumkan inisial nama demi menjaga kerahasiaan subjek. Penelitian ini dilakukan sangat mendalam dan komprehensip yang didapatkan berkaitan dengan apa-apa yang disampaikan orangtua kepada peneliti dan melihat secara langsung sikap anak-anaknya. Seluruh subjek memang benar-benar mengalami dan bersedia untuk digali datanya secara mendalam. Sebagian subjek menyatakan bahwa pola asuh mereka diterapkan karena mengikuti dari zaman nenek moyang mereka, hal ini menjadi menarik untuk diteliti karena pola asuh yang dulu mungkin tidak akan menjadi acuan di zaman milenial sekarang, karena akan membuat trauma yang mendalam bahkan kejiwaannyapun akan terganggu. Hal ini yang perlu diluruskan agar kedepannya anak-anak menjadi panutan ummat khususnya keluarga. Data diperoleh melalui wawancara mendalam secara face to face kepada subjek, yang dilakukan secara langsung untuk menjaga kenyamanan dan kerahasiaan nama subjek. Analisis data yang dilakukan oleh peneliti untuk mendapatkan informasi tentang pola asuh orangtua terhadap perilaku anak berlangsung sejak awal penelitian, reduksi data dan triangulasi data (termasuk di dalam reduksi fenomenologis, reduksi eidetic, dan reduksi trensendental), sehingga pengambaran fenomena yang sesungguhnya dilakukan secara teliti dan hati-hati.

\section{Hasil dan Pembahasan}

\section{Pola Asuh Orang Tua dalam Menyikapi Perilaku anak Bermain gadget}

Subjek dalam penelitian ini diberi nama dengan inisial $\mathrm{AA}, \mathrm{AB}, \mathrm{MH}$, 
MK, dan HY. Semua subjek berasal dari keluarga kurang mampu sampai keluarga yang berada. AA berprofesi sebagai pegawai pemprov, $\mathrm{AB}$ berprofesi sebagai pedagang, $\mathrm{MH}$ berprofesi sebagai tenaga pendidik honorer, $\mathrm{HY}$ berprofesi sebagai tenaga pendidik PNS sedangkan MK berprofesi sebagai petani. Masing- masing mempunyai anak dari 3 sampai 4 orang, baik itu laki-laki maupun perempuan. Seluruh subjek menunjukkan respon yang berbeda-beda terkait dengan pola asuh orangtua yang diterapkan. Ada tiga jenis pola asuh yang terjadi di masyarakat yaitu sebagai berikut:

1. Pola asuh otoriter

Pola asuh ini, orang tua memiliki aturan yang kaku dalam mengasuh anak-anaknya. Pada pelanggaran yang dilakukan akan diberikan sanksi. Pola asuh ini bersifat memaksa dan cenderung tidak mengenal kompromi. Orang tua menerapkan pola asuh ini ketika sedang berinteraksi dan berkomunikasi dengan anak, orang tua memberikan arahan kepada anak dengan tegas tanpa adanya perlawanan dari anak itu sendiri, seperti yang diungkapkan oleh $A B$ bahwa: "Setiap anak dididik sama, baik anak pertama atau pun kedua, harus keras karena jika kita sebagai orangtua lemah, anak akan semena-mena. Apalagi dimasa pandemi sekarang, orangtua harus ekstra mendidik anak jika ia selalu membuat kesalahan. Maka akan diberi sanksi atau hukuman secara langsung, HP-nya akan disita, uang jajan dikurangi bahkan sampai dipukul.9

Wawancara di atas menunjukkan bahwa orangtua memang sangat keras dalam mendidik anak. Hasil wawancara menunjukkan oreang tua bersikap otoriter supaya anak patuh dan taat pada orangtua. Itu yang membuat persepsi mereka ingin menjadikan anak-anaknya menjadi hormat dan bakti padanya.

2. Pola Asuh Demokratis

Pola asuh demokrasi dikatakan pola asuh yang paling baik. Karena pada halnya orang tua bersikap friendly kepada anak dan anak bebas mengemukakan pendapatnya sendiri, peran orang tua lebih mau mendengarkan keluh kesah yang disampaikan anaknya, mau memberikan masukan dan nasehat yang baik. Dalam pola asuh ini, orang tua memprioritaskan kepentingan anak, akan tetapi tidak ragu-ragu untuk mengendalikan mereka, tidak berharap lebih yang melampaui kemampuan anak, hukuman yang diberikan tidak pernah kasar serta pendekatannya lemah lembut.

Berdasarkan hasil pengamatan bahwa pola asuh demokratis memberikan dampak positif pada perilaku anak, pola asuh yang baik akan membuat pribadi anak menjadi lebih terarah, tentunya perhatian dan kasih sayang sangat diperlukan seperti yang dinyatakan oleh AA "Dalam mendidik anak, diperlukan kesabaran yang ekstra. Anak sebagai titipan yang harus dijaga dengan baik, agar tidak menyakiti hatinya ataupun sampai membuat psikologinya terganggu.

\footnotetext{
${ }^{9}$ Wawancara pada hari kamis, 19 November 2020 jam 01.22
} 
Semua kehendak orangtua pastilah ingin yang terbaik buat anaknya. Apa yang diinginkan anak, itulah yang menjadi keputusannya. orangtua hanya bisa memberikan nasehat yang baik untuk kedepannya. Kesuksesan anak bukan tergantung pada orangtua akan tetapi nasib anak manusia tidak ada yang tahu".10

Subjek MH lebih jelas lagi dalam mengungkapkan pola asuh dalam mendidik anak-anaknya agar kedepannya bisa membentuk perilaku yang baik yaitu: Dalam mendidik anak tidak perlu adanya kekerasan, seperti main tangan ataupun hal lainnya. Karena itu akan membuat psikologi anak dari kecil hingga dewasa mengaumsikan bahwa orangtua menyakitinya bahkan sampai memukul. Maka dari itu, disaat datangnya pandemi, anak-anak memang lebih disibukkan dengan gadget, tapi saya memberikan waktu untuk anak kapan dia bermain dengan gadgetnya kapan waktunya tidak, saya tidak menerapkan konsep pola asuh dengan kekerasaan. Kalau anak nakal biarkan saja, lambat laun ia akan mengerti dan memahami mana yang baik dan mana yang buruk. Orangtua hanya memberikan nasehat contoh tauladan yang baik agar anak juga bisa mengikuti dengan baik. Dengan demikian perilakunya akan mengikuti dari nasehat-nasehat orangtua sendiri”. 11

Hasil wawancara di atas menggambarkan bahwa pengasuhan yang bersifat lemah lembut dan tidak memaksakan kehendak akan memberikan dampak positif terhadap perilaku anak. Jika pola asuhnya baik anak akan mengikuti perintah orang tua. Hal tersebut didukung atas hasil wawancara dengan HY yang memberikan respon yang cukup positif terkait dengan cara mendidik anak yaitu:"Dalam mendidik anak saya membebaskan untuk menemukan karakternya sendiri, akan tetapi tidak lepas dengan tanggung jawab untuk memberikan arahan dan pandangan ke depan untuk menjadi yang lebih baik.Untuk urusan agama saya lebih tegas kepada anak. Dari sejak kecil saya biasakan untuk wajib membaca alquran setiap harinya setelah selesai sholat lima waktu, minimal satu lembar. Apabila anak melanggar akan saya beri sanksi berupa hapalan surah-surah pendek.12

Dari pernyataan informan di atas maka penulis dapat menyimpulkan bahwa pola asuh yang bersifat demokratis memberikan dampak positif bagi perilaku anak. Sebab terjalinnya hubungan yang erat dan lemah lembut antara orang tua dan anak maka sangat berpotensi untuk menciptakan intraksi yang baik dalam sebuah keluarga.

3. Pola Asuh Permisif

Pola asuh permisif diartikan sebagai cara mendidik dengan membiarkan

\footnotetext{
${ }^{10}$ Wawancara pada hari senin, 16 November 2020 jam 07.44

${ }^{11}$ Hasil wawancara pada hari senin, 16 November 2020

${ }^{12}$ Hasil wawancara pada hari rabu, 18 November 2020
} 
anak berbuat sekehendaknya, orang tua tidak memberi pimpinan, nasehat maupun teguran terhadap anaknya.13 Pola asuh permisif merupakan kebebasan pada anak tanpa kontrol, orang tua tidak memberikan teguran dan tidak memperingatkan apabila anak melakukan suatu kesalahan, sedikit memberikan bimbingan tetapi sering memanjakannya. Apapun yang diminta anak orang tua pasti mengabulkannya.

Pengasuhan yang dilakukan oleh orang tua yang bersifat permisif memberikan dampak negatif pada perilaku anak, berdasarkan hasil pengamatan di lapangan bahwa memberikan kebebasan kepada anak dengan berlebihan tanpa adanya kontrol yang cukup serta sering memanjakannya akan berdampak negatif pada perilakunya. Pernyataan di atas diperkuat dengan hasil wawancara oleh subjek MK, bahwa: "Saya sangat memanjakan anak-anak saya, apapun yang mereka inginkan saya kabulkan, karena anak adalah titipan yang harus dijaga dan tidak boleh dikasari. Dari uraian di atas dapat diketahui bahwa orang tua memberikan kebebasan kepada anaknya, selalu memanjakannya, tidak memberikannya nasihat atau teguran. penulis memberikan suatu gambaran bahwa pola asuh permisif memberikan dampak negatif pada perilaku anak baik di luar rumah maupun di dalam rumah. Karena tidak adanya suatu kontrol yang kuat pada anak dan sering memanjakan sehingga anak sewenang-wenangnya melakukan sesuatu tanpa berpikir bahwa itu adalah buruk.

Pola asuh orangtua terkait dengan data hasil wawancara dan observasi menunjukkan bahwa latar belakang orang tua sangat berpengaruh dalam memberikan pengawasan terhadap perilaku anak. Menurut Tri, yang menyatakan bahwa perilaku sosial merupakan tindakan interaksi antar individu dalam membangun sebuah hubungan yang saling berkaitan, dan perilaku sosial individu dipengaruhi oleh beberapa faktor. Faktor yang paling dominan adalah faktor lingkungan dimana individu itu berada, berdampak pada pola kebiasaan yang lama-lama menjadi ciri khas suatu perilaku dari individu tersebut. Jika perilaku anak mengalami penyimpangan maka hal itu adalah efek dari penggunaan gadget yang berkelanjutan di era pandemi ini.14

Penelitian lain yang memiliki latar belakang orang tua yang beragam tidak semua menerapkan kebiasaan-kebiasaan kedisiplinan terhadap anak dengan cara yang sama. Kemudian latar belakang perekonomian tidak memberikan peran dalam mengasuh dan motivasi belajar anak sehingga hal tersebut dapat dikatakan tidak begitu memberikan hasil yang nyata bagi anak. Hal tersebut

${ }_{13}$ Tria Novasari, "Pengaruh Pola Asuh Orang Tua Terhadap Perilaku Sosial (Studi Pada Siswa Kelas X Smkn 5 Surabaya)," Kajian Moral dan Kewarganegaraan 4, no. 3 (August 31, 2016), accessed January 10, 2021, https://jurnalmahasiswa.unesa.ac.id/index.php/jurnalpendidikan kewarganegaraa/article/view/17221.

14 Tri A., F. L. (2016). Perilaku Sosial Anak Usia Dini di Lingkungan Lokalisasi Guyangan 2016. Jurnal Pendidikan Usia Dini, 10 (1), 121-134. 
memberikan makna bahwa belum tentu keluarga yang memiliki ekonomi yang tinggi mampu memberikan nilai poitif terhadap proses belajar dan perilaku anak begitupun sebaliknya. Penggunaan gadget di era pandemi ini menimbulkan efek yang buruk jika dalam jangka waktu yang lama. Penelitian terdahulu menyebutkan bahwa gangguan perilaku dalam hubungannya dengan akademik yakni ketidakmampuan adaptasi dalam interaksi sosial di sekolah dan perilaku yang tidak mendukung pembelajaran. Gangguan perilaku tersebut menyebabkan mereka mengalami masalah baik itu dalam hubungan sosial dengan teman, guru, masalah dalam rutinitas pembelajaran dan beresiko mengalami kerugian atau kecelakaan fisik karena perilaku bermasalah yang mereka lakukan disaat pandemi ini.15

\section{Dampak Penggunaan Gadget}

Teknologi sekarang semakin canggih menyebabkan anak yang masih berusia dini pun sudah mampu mengoperasikan gadget. Teknologi menawarkan berbagai variasi dalam proses mempelajari hal-hal baru dengan mudah. Teknologi yang sangat mungkin menghadirkan stimulus suara dan visual di saat yang bersamaan, membuat anak mampu mempelajari banyak hal dalam waktu yang sangat cepat. Terutama sejak munculnya gadget yang memiliki kehebatan akses yang cepat dengan harga yang terjangkau telah mengakibatkan makin banyak orang yang mampu memilikinya. Bahkan dalam keluarga tertentu, gadget bisa saja telah dimiliki oleh anak sekolah mulai dari SD, SMP maupun SMA, termasuk anak balita.16

Orang tua juga pada akhirnya sudah banyak yang memberikan teknologi kepada anak. Tanpa disadari, banyak anak yang sudah kecanduan gadget dan akhirnya berperilaku menyimpang. Hal tersebut masih di anggap sepele orangtua, secara tidak sadar gadget sudah mempengaruhi kehidupan anak-anak bahkan menjadi kebutuhan yang sangat penting bagi anak.17

Orang tua merupakan pemegang kendali utama atas proses pembentukan karakter anak. Pada saat ini terjadi pergeseran nilai kesusilaan pada. Di level itu, peran orang tua menjadi sangat penting untuk memberikan pemahaman kepada anak sebelum mereka terjun ke masyarakat. Karena itu, teladan sikap orang tua sangat dibutuhkan bagi perkembangan anak-anak. Hal

15 Ika Rizki Ramadhani, Irfai Fathurohman, and Much Arsyad Fardani, "Efek Penggunaan Smartphone Berkelanjutan Pada Masa Pandemi Covid-19 Terhadap Perilaku Anak," Jurnal Amal Pendidikan 1, no. 2 (August 31, 2020): hlm. 100 .

${ }^{16}$ M. Hafiz al-ayouby, "dampak penggunaan gadget pada anak usia dini (studi di paud dan TK.Handayani Bandar Lampung)," Skripsi (Universitas Lampung: Fakultas Ilmu Sosial Dan Ilmu Politik, May 9, 2017), last modified May 9, 2017, accessed January 10, 2021, http://digilib.unila.ac.id/27131/.

17 Ika Rizki Ramadhani, Irfai Fathurohman, and Much Arsyad Fardani, "Efek Penggunaan Smartphone Berkelanjutan Pada Masa Pandemi Covid-19 Terhadap Perilaku Anak," Jurnal Amal Pendidikan 1, no. 2 (August 31, 2020): 96-105. 
ini penting karena pada fase perkembangan manusia, usia anak adalah tahapan untuk mencontoh sikap dan perilaku orang yang ada di sekitar mereka.18

Peran orang tua yang muncul selama pandemi ini adalah sebagai pembimbing dan pendidik. Menjaga dan memastikan anak untuk menerapkan hidup sehat, mendampingi anak dalam mengerjakan tugas sekolah, menjalin komunikasi yang intens dengan anak, bermain bersama anak, menjadi role model bagi anak, dan membimbing dan memotivasi anak dalam penggunaan gadget sesuai dengan kebutuhannya.19

Gadget memiliki banyak manfaat terutama dalam penggunaan yang benar sesuai fungsi dan tujuan utamnya. Menurut Handrianto (2013 dalam Juliadi, 2018), mengatakan bahwa gadget mempunyai dampak positif dan negatif.20 Dampak tersebut antara lain adalah:

1. Dampak positif

Di antara beberapa dampak positif dari bermain gadged adalah :

a. Berkembangnya proses imajinasi, baik dalam hal melihat gambar, kemudian menggambarnya sesuai dengan imajinasinya yang mampu melatih daya pikir tanpa dibatasi oleh kenyataan.

b. Melatih kecerdasan otak, anak dapat terbiasa dengan tulisan, angka dan gambar yang dapat membantu melatih proses belajar.

c. Meningkatkan rasa percaya diri anak.

d. Mengembangkan kemampuan membaca, menghitung dan memecahan suatu problem. 21

2. Dampak negatif

Dampak negatif dari bermain gadged adalah :

a. Daya konsentrasi saat belajar menurun, pada saat belajar anak menjadi tidak fokus karena teringat gadget, misalnya anak teringat dengan permainan gadget seolah-olah dia seperti tokoh utama dalam game tersebut.

b. Malas menulis dan membaca, hal ini diakibatkan karena seringnya menggunakan gadget misalnya pada saat anak membuka vidio di aplikasi youtube anak cendeung melihat gambarnya saja tanpa harus menulis apa yang mereka cari.

c. Lemahnya kemampuan dalam bersosialisasi, misalnya anak kurang bermain dengan teman dilingkungan sekitarnya, tidak memperdulikan keadaan

18 Dewi Fortuna Solina, Digital Parenting Terhadap Anak Pada Masa Pandemi Covid-19, Universitas Padjadjaran.

${ }^{19}$ Euis Kurniati, Dina Kusumanita Nur Alfaeni, Fitri Andriani, Analisis Peran Orang Tua dalam Mendampingi Anak di Masa Pandemi Covid-19, Jurnal Obsesi, 2021, hlm. 253.

20 Juliadi. Penyebab Penggunaan Gadget Pada Remaja. Skripsi. Tidak Diterbitkan. FKIP Program Studi Bimbingan Konseling Universitas Riau Kepulauan Batam.

21 Novitasari, W., \& Khotimah, N. (2016). Dampak penggunaan gadget terhadap interksi sosial anak usia 5-6 tahun. Paud Teratai, 5(3). 
disekelilingnya, fokus dengan gadget sehingga ia tidak peduli dengan orangorang yang berada disekitarnya.

d. Kecanduan gadget, anak akan sulit dan akan bergantung dengan gadget karena sudah menajadi baian penting dalam kebutuhannya.

e. Dapat menimbulkan gangguan kesehatan, seperti halnya karena sering memegang dan melihat gadget maka paparan radisasi yang ada pada gadget selalu memantulkan ke arah kita terlebih lagi sangat merusak kesehatan mata.

f. Perkembangan kognitif anak terhambat, kognitif atau pemikiran psikologis yang berkaitan dengan bagimana anak mempelajari, memperhatikan, mengamati, membayangkan, memperkirakan, menilai dan memikirkan lingkungannya akan terhambat.

g. Menghambat kemampuan berbahasa, anak yang terbiasa menggunakan gadget akan cenderung diam, sering menirukan bahasa yang didengarnya bahkan bahasa yang ia gunakan berubah menjad bahasa gadget.22

Hasil wawancara mengatakan bahwa anak menggunakan gadget untuk bermain game online dan menonton youtube, sesekali anak juga menggunakan whatsapp untuk berkomunikasi dengan teman dan membuka internet untuk belajar. Sebenarnya, jika digunakan dengan baik gadget memiliki dampak positif bagi anak antara lain sebagai sarana penunjang dalam pendidikan. Selain dampak positif, ada pula dampak negatif yang dapat dirasakan saat menggunakan gadget yaitu anak menjadi malas melakukan aktivitas, anak menjadi mudah marah, saat diberi tahu anak membangkang, anak meniru tingkah laku yang ada pada game dan membuat mata anak menjadi sakit bahkan anak tidak mengenal waktu disiplinnya untuk menjaga kesehatan dan kebersihan tubuhnya di masa pandemi covid 19.23

Berdasarkan uraian mengenai dampak positif dan negatif dari penggunaan gadget diatas, maka dapat disimpulkan bahwa gadget merupakan alat komunikasi yang digunakan untuk memudahkan semua orang baik kalangan muda maupun tua dalam proses berkomunikasi, namun disamping itu, terdapat beberapa manfaat dan kerugian yang di timbulkan oleh gadget itu sendiri, apakah itu bertujuan untuk hal yang bermanfaat atau hal yang tidak berguna. Untuk itu perlu adanya pengawasan yang ekstra dari orangtua terhadap penggunaan media teknolgi yaitu gadget agar anak- anak menjadi lebih baik dalam hal apapun. 24

22 Ilga Maria and Ria Novianti, "The Effects of Using Gadgets during the Covid-19 Pandemic on Children's Behaviour," Alfäluna: Journal of Islamic Early Childhood Education 3, no. 2 (October 4, 2020): 74-81.

${ }^{23}$ Layyinatus Syifa, Eka Sari Setianingsih, and Joko Sulianto, "Dampak Penggunaan Gadget terhadap Perkembangan Psikologi pada Anak Sekolah Dasar," Jurnal Ilmiab Sekolah Dasar 3, no. 4 (2019): 527-533.

${ }_{24}$ M. Hafiz Al-Ayouby, Dampak Penggunaan Gadget Pada Anak Usia Dini, Skrips (Lampung: Universitas Lampung), 2017, hlm. 20-22 
Temuan lain juga menyatakan bahwa peran orang tua memegang peranan yang sangat penting bagi perkembangan anak, sehingga orang tua diharapkan mampu mengoptimalkan perannya sebagai fasilitator, motivator dan pembimbing dalam tumbuh kembang anak serta membimbing, mengawasi anak dalam hal penggunaan gadget sehingga pemakaian gadget dapat dioptimalkan sebagai alat yang memberi kemudahan bagi anak untuk belajar dan berprestasi bukan sebaliknya.25 Pernyataan yang sama juga dipertegas, peran orangtua terhadap anak-anaknya harus selalu dilakukan. Jangan sampai orangtua mengandalkan gadget untuk menemani anak-anaknya. Mengontrol setiap konten yang ada pada gadget anak, lebih sering mengajak anak untuk berdiskusi, tanya jawab dalam waktu luang. Selama waktu itu anak bisa meniru tingkah laku orang dewasa mengembangkan daya imajinasi dan kreatifitasnya. 26

\section{Penutup}

Pada masa pandemi Covis 19, gadged dijadikan sebagai salah satu media pembelajaran bagi anak. Agar gadget tidak menimbulkan dampak negatif bagi perkembangan anak, maka orang tua menjadi penentu dalam mengantisipasi dampak negatif penggunaan gadget. Dalam menyikapi dampak negatif penggunaan gadget, orang tua memiliki poa asuh yang bermacam-macam, ada yang otoriter, demokratis dan permisif. Namun secara umum, dalam menyikapi perilaku anak yang bermain gadget, hasil penelitian menunjukkan bahwa orang tua orang tau cenderung menggunakan poal asuh demokratis. Orang tua memberikan pengertian tentang dampak negatif dari penggunaan gadget dan memberikan pengawasan terhadap anaknya agar menggunakan gadget untuk halhal yang positif. Namun ada juga yang menerapkan poa asuh otoriter. Pada pola asuh ini, orang tua cenderung melarang anak-anaknya untuk bermain gadget dan menerapkan hukuman kepada anak jika melanggar ketentuan yang telah disepakati. Selain itu, ada juga yang menerapkan pola asuh permisif, yaitu orang tua cenderung membiarkan anaknya, tanpa memberikan pengawasan dan kontrol terhdap anaknya dalam bermain gedget. Polah asuh yang permisif ini pada gilirannya dapat menyebabkan anak terpengaruh dampak negatif dari penggunaan gadget.

\section{Daftar Pustaka}

al-Ayouby, M. Hafiz, Dampak Penggunaan Gadget Pada Anak Usia Dini, Skrips

25 I Gusti Agung Ayu Wulandari, Christopher Damian Unisi Naibaho, Kontribusi Intensitas Pemakaian Gadget dan Peran Orang Tua Terhadap Hasil Belajar Matematika Siswa Kelas V SD, Jurnal Pedagogi dan Pembelajaran, JP2 Vol. 4 No. 1, Tahun 2021, hlm. 66.

${ }_{26}$ Puji Asmaul Chusna, "Pengaruh Media Gadget Pada Perkembangan Karakter Anak," Dinamika Penelitian: Media Komunikasi Penelitian Sosial Keagamaan 17, no. 2 (December 3, 2017): 315-330. 
(Lampung: Universitas Lampung), 2017, hlm. 20-22

Anisah, A. S. (2017). Pola asuh orang tua dan implikasinya terhadap pembentukan karakter anak. Jurnal Pendidikan UNIGA, 5(1), 70-84.

Christopher Damian Unisi Naibaho,I Gusti Agung Ayu Wulandari, Kontribusi Intensitas Pemakaian Gadget dan Peran Orang Tua Terhadap Hasil Belajar Matematika Siswa Kelas V SD, Jurnal Pedagogi dan Pembelajaran, JP2 Vol. 4 No. 1, Tahun 2021, hlm. 66.

Chusna, Puji Asmaul. "Pengaruh Media Gadget pada Perkembangan Karakter Anak." Dinamika Penelitian: Media Komunikasi Penelitian Sosial Keagamaan 17, no. 2 (December 3, 2017): 315-330.

Eka Setiawati, Elih Solihatulmillah, Habib Cahyono, Dewi A, "The Effect of Gadget on Children's Social Capability", Journal of Physics: Conference Series, 2019, hlm. 1

Indian Sunita \& Eva Mayasari, Pengawasan Orangtua Terhadap Dampak Penggunaan Gadget Pada Anak, Journal Endurance: Stikes Al-Insyirah Pekanbaru, 2018, hlm. 511.

Juhardin, H. Jamaluddin Hos. "Dampak Pola Asuh Orang Tua Terhadap Perilaku Anak (Studi Di Desa Amberi Kecamatan Lambuya Kabupaten Konawe)." Jurnal Neo Societal 1, no. 0 (July 20, 2016). Accessed January 10, 2021.

Kurniati, Euis, Dina Kusumanita Nur Alfaeni, Fitri Andriani, Analisis Peran Orang Tua dalam Mendampingi Anak di Masa Pandemi Covid-19, Jurnal Obsesi, 2021, hlm. 253.

Maria, Ilga, and Ria Novianti. "The Effects of Using Gadgets during the Covid19 Pandemic on Children's Behaviour." Ațfāluna: Journal of Islamic Early Childhood Education 3, no. 2 (October 4, 2020): 74-81.

M. Hafiz al-ayouby, "Dampak Penggunaan Gadget Pada Anak Usia Dini (Studi Di PAUD dan TK.Handayani Bandar Lampung)." Skripsi. Universitas Lampung: Fakultas Ilmu Sosial dan Ilmu Politik, May 9, 2017. Last modified May 9, 2017. Accessed January 10, 2021. http://digilib.unila.ac.id/27131/.

M shaw. Susan, $M$ shaw. Family Leisure and Changing Ideologies of Parenthood, Journal Compilation: Sosiology Compas,2008, hlm. 689.

Novasari, Tria. "Pengaruh Pola Asuh Orang Tua Terhadap Perilaku Sosial (Studi Pada Siswa Kelas X Smkn 5 Surabaya).” Kajian Moral dan

Kewarganegaraan 4, no. 3 (August 31, 2016). https://jurnalmahasiswa.unesa.ac.id/index.php/jurnal-pendidikankewarganegaraa/article/view/17221. 
Novitasari, W., \& Khotimah, N. (2016). Dampak penggunaan gadget terhadap interksi sosial anak usia 5-6 tahun. Paud Teratai, 5(3).

Ramadhani, Ika Rizki, Irfai Fathurohman, and Much Arsyad Fardani. "Efek Penggunaan Smartphone Berkelanjutan Pada Masa Pandemi Covid-19 Terhadap Perilaku Anak.” Jurnal Amal Pendidikan 1, no. 2 (August 31, 2020): 96-105.

Sahriana, Nanang, "The Importance of the Role of Parent in the Use of the Gadget at Early Childhood", Journal Smart PAUD, 2019, hlm. 60.

Syifa, Layyinatus, Eka Sari Setianingsih, and Joko Sulianto. "Dampak Penggunaan Gadget terhadap Perkembangan Psikologi pada Anak Sekolah Dasar.” Jurnal Ilmiah Sekolah Dasar 3, no. 4 (2019): 527-533.

Solina, Dewi Fortuna,Digital Parenting Terhadap Anak Pada Masa Pandemi Covid-19, Universitas Padjadjaran.

Tri A., F. L. (2016). Perilaku Sosial Anak Usia Dini di Lingkungan Lokalisasi Guyangan 2016. Jurnal Pendidikan Usia Dini , 10 (1), 121-134. 
92 | Islamic Counseling: Jurnal Bimbingan dan Konseling Islam, Vol. 5, No. 1, 2021

Halaman ini Sengaja Dikosongkan 